\title{
THE IMPORTANCE OF PARENTAL ATTITUDE IN NEGATIVE CHILDHOOD EXPERIENCE
}

https://doi.org/10.37096/SHDISJ-20-2.2-0010

Tselikova Yulia

ORCID ID: 0000-0002-8029-8462

\begin{abstract}
The article is devoted to the peculiarities of the manifestation of negative childhood experiences among the adult population of Ukraine with a focus on childparent relationships and attitude, which could lead to certain negative early memories, and have traumatic psychological consequences. Thus, the aim is to study children's negative memories of adult respondents with different types of parental attitudes, which the latter encountered during childhood. With the help of modification of the original questionnaire ACE (Adverse childhood experience) questionnaire a qualitative and quantitative analysis have been conducted on the types of psychological traumas, their prevalence and intensity among the respondents, as well as significant relationships between them. Compared with previous studies on this issue, this research covers the older generation of respondents, so we are able to explore the features of traumatic psychological memories of people who passed the stage of childhood in about 30 years ago. In the article it is presented a rating of the most and least harmful and dangerous events for the psychological health of the child, and their negative consequences in adult life, provides assumptions about the causal connections, as well as substantiates the results. In combination with the data obtained from the questionnaire of child-parental attitude, developed by A.Ya. Varga and V. V. Stolin, we have found the correlations with some of negative psychological experience in childhood. A broader picture of how the type of control and level of distance, patterns of behavior, attitudes, perceptions and responses of adults, such as infantilization, rejection, ignoring, inability to give a sense of security and equality, independence and freedom, love and respect, to see the child as a person with his own thoughts, needs, etc., inherent in specific memories of emotional neglect and physical violence have been presented. Thus, the results have showed the relevance of research in this area.
\end{abstract}

Keywords: adverse childhood experiences, parental attitudes, child-parent relationships, ACE questionnaire, mental health.

\section{Introduction}

The formation of personality takes place throughout life, but the foundation of such a "building" is laid within the family. And to understand better if it will be a skyscraper with the best equipment, or an abandoned house with variety of problems, we should pay attention to a family system, where a kid grows. Many earlier studies (Freud, 1960; Adler, 1997; Brun, 1990; Burmenskaya, Karabanova,
1990; Felitti, Anda, Nordenberg, Williamson, Spitz, Edwards, Koss, Marks, 1998; Kaplan, Pelcovitz, Bruna, 1999; Sibling, Ortiz, 2017; Milyutina, 2018; Tytarenko, 1987, etc.) showed that the connection between children's negative memories and health problems, relationship building, social success in adulthood is undeniable. The combination of parental attitudes methods and ACE (adverse childhood experience) 
questionnaire makes it possible to explore the psychological experience of the child in both favorable and destructive family systems, and see their consequences.

The purpose of the article is to identify and analyze the most typical psychologically harmful situations faced by a minor in their close environment (using a modification of $\mathrm{ACE}$ questionnaire), as well as the role of parental attitude in childhood memories, their positive or nrgative influence on personality (questionnaire of parental attitude A.Y. Varga, V.V. Stolin).

\section{Theoretical background}

Childhood experience is an invaluable source of information for understanding the characteristics of an adult. Three classical thoughts of $\mathrm{Z}$. Freud, A. Adler, and A.R. Brun prove it. Freud's says that under the influence of mental mechanisms of information processing early memories turn to the story that reflects the child's real perception of own experience (Freud, 1960). Another position on the significance of early memories is also empirically confirmed in practical work of A.Adler and proves that both fictional and real childhood memories are the autobiographical history of the individual, which determines the basic attitudes, life positions, coping strategies, self-esteem, worldview, interests, fears, personality needs etc., and also has a prognostic value for the further development of human life (Adler, 1997). In turn, his follower A.R. Brun says, that those areas of adult life in which difficulties arise are directly related to childhood situations that are engraved in the memories as those that psychologically traumatized the child (Bruhn, 1990). Whatever these areas of life are, the most of significant childhood experience received within a family. The same opinion is held by researcher V. Ya. Tytarenko, who assigns a leading role to the family in "the formation of such qualities and personality traits that will help to overcome with dignity the difficulties and obstacles encountered in life" (Titarenko, 1987). According to the World Health Organization, child abuse can be described as "any form of physical and/or emotional abuse, sexual violence, neglect or negligence, commercial or other exploitation that results in actual or potential harm to health or the dignity of the child " (Petersen, Aber, Billingsley, Brooks-Gunn, Cohen, Conte, Egeland, Hetherington, Horwitz, Korbin, Lewis, Little, Straus, Widom, Wyatt, Chalk, Backer, MacGuffie, 1993).

The problem of child-parent relationship studied quite widely (Varga, 1986; Bevz, 2009; Burmenskaya, Karabanova, 1990; Milyutina, 2018; Maksimova, 2011; Titorenko 1987; Kaplan, Pelcovitz, Bruna, 1999; Preethy, Somasundaram, 2020). According to A.Ya. Varga parental attitude is a set of ideas, stereotypes, behavioral and emotional reactions, which are expressed in the process of interaction with the child. These include proximity or distance from the child, acceptance or rejection, and the type of control directed at the child (Golubeva, Istratova, 2009). Researchers say that early memories, childhood experience have an undeniable impact on children's perceptions of the future and can also create obstacles in the perception of own child. When it comes to negative childhood experiences we are more likely to imagine a troubled family (or, as indicated in the regulations - "family in difficult life circumstances"): the lack of ability to provide basic needs and living conditions, lack of work for able-bodied 
family members, imprisonment of family members, alcohol or drug addiction from parents side, violence, abuse, neglect etc (Maksimova, 2011). There are also studies about affective disorders within drug addicted families and parent-child relationship, which include verbal aggression aimed to reducing emotional anxiety (Kaplan, Pelcovitz, Bruna, 1999). However, if a family is not difficult, it doesn't guarantee that it's environmentally friendly for a child. Practitioner psychologists note that "counseling is increasingly faced with a decrease in the duration and impoverishment of family communication, lack of warmth, attentiveness to each other, the disappearance of truly common forms of useful activities of children with adults or leisure. The place of personal and cognitive communication is engaged in its narrowly pragmatic forms: the introduction of regime, control over academic performance, and the encouragement of children to material format" (Burmenskaya, Karabanova, 1990).

Modern studies are agree with that, and show that parents can not find enough time for quality interaction with children nowadays: in India, 48\% of parents can spend less than 8 hours a day with their child. Thus, when parents are absent or working, children are cared for by their family members $(72.3 \%)$, or by kindergarten staff and school teachers $(13.9 \%)$. This, in turn, plays a vital role in the child's growth and development, as any form of abuse or neglect during this period, whether physical, emotional or mental, can have significant and farreaching consequences for the child. (Preethy, Somasundaram, 2020). The relationship between parents themselves also extremely important for the development of the young personality, because it becomes a basis, an example for future life of a kid, mostly unconsciously. Thus, various traumatic situations in childhood cause strong feelings and are engraved in early childhood memories. The parental position reflects the patterns of interaction with children, which are determined by different combinations of behavioral, cognitive and emotional components (Varga, 1986). Therefore, the relationship between negative childhood memories with different types of parental attitudes are relevant.

\section{Methodology}

The study has been conducted in one stage by modifying the ACE questionnaire (Adverse Childhood Experience) and the questionnaire of parental attitudes A.Ya. Varga, V.V. Stolin. The original ACE questionnaire has been developed as a part of a largescale study of adverse childhood experiences by Kaiser Permanente Medical Center and the USA Centers for Disease Control and Prevention (Felitti, Anda, Nordenberg, Williamson, Spitz, Edwards, Koss, Marks, 1998). In our case, the questionnaire has been modified for the needs of the study, because 10 original questions combined different types of violence in one, so the modification separates them to 20 with different types of violence and traumas, includes experience of serious illness and school bullying" (Milyutina, 2018). The Parent Attitude Questionnaire contains 61 questions, which are formed into scales to count the points that reflect the features of parental attitudes aspects (Varga, 1986). The study has involved 73 people (52 women, 21 men), teachers and students of the Faculty of Psychology of Taras 
Shevchenko National University, aged from 21 to 60 .

\section{Results}

Let's introduce the statistics of responses to adverse childhood experience with a help of visualization (Fig. 1, frequency of positive responses occurrence to the ACE questionnaire):

\title{
Percentage of traumatic childhood memories
}

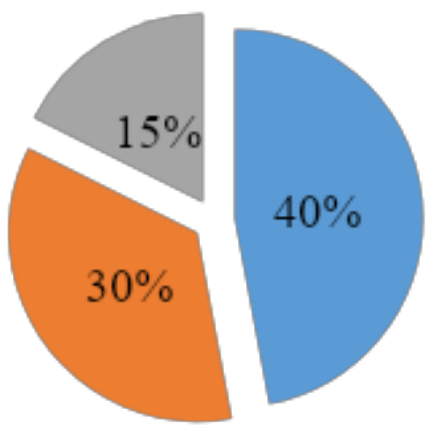

\author{
- from 0 to 5 replies "yes" \\ from 6 to 10 replies "yes" \\ from 11 to 15 replies "yes"
}

Fig. 1, Frequency of positive responses occurrence to the ACE questionnaire

As we can see, up to 5 traumatic memories have $40 \%$ of respondents; $30 \%$ can remember from 6 to 10 of such situations; between 11 and 15 "yes" were obtained among $15 \%$ of study participants and we didn't have cases with more than 15 negative memories. A significant difference between this and previous work is that the first study did not identify situations of imprisonment of family members (Tselikova, 2019). This time we also cannot answer four more questions, as №6 (sexual experience under 18 with an adult partner), №15 (imprisonment situation), №17 (suicide issue in the family) and №18 (closure) in the room or tethering).

Next step is to introduce the percentage prevalence of positive responses to the ACE questionnaire. Almost half of the respondents $(48 \%)$ faced in their childhood with fear of physical harm, were hospitalized with a serious illness and were punished with silence and ignorance. The second most frequent manifestations were memories related to the lack of closeness and supportive relationships (32\%) and the frequent feeling that "I am despised and not loved" (29\%); as well as living with alcohol or drug addicted family members and sexual hints from an adult (22\%). In between $19-12 \%$ we had cases of physical violence, adverse life circumstances, regular abuses and humiliation; divorce or separate residence of parents; regular beating, pushing, grabbing of oneself or (and) mother; school bullying and a sense of greater care of a sibling. And the last, the smallest, $3 \%$ experienced lack of food and clean clothes, armed threats to the mother or (and) other family members, as well as living with a mentally ill relative. Children from such families have up to 15 positive answers to the ACE questionnaire and can be said to have had the most difficult childhood compared to other respondents.

Correlation analysis by Pearson's criterion gave the following results. Since in this study most participants were from 30 to 45 y.o., we have significant 
correlations with age. The older the sample was, the more such childhood memories as lack of food and clean clothes $\left(0.466^{* *}\right)$, beatings to bruises $\left(0.364^{*}\right)$ and living with a family member who had alcohol or drug addiction $\left(0.583^{*}\right)$ we had. At the same time, families where parents are unable to cover basic needs of their children, we found severe physical punishment, abuse, humiliation $\left(0.375^{*}\right)$ and violence against the mother $\left(0.416^{*}\right)$. Unambiguous link between alcohol/drug-addicted parents and regular physical violence witnessed by children $\left(0.602^{* *}\right)$ or armed threats $\left(0.416^{*}\right)$ and fear that one of the adults will cause physical harm (0.403*). Lifestyle of such families explains the negligence of parents due to substance addiction, as well as the use of corporal punishment within the norm of upbringing. Living with a mentally ill family member or where armed threats are often thing are the most dangerous for the child's mental health. Both situations correlate with each other $(1 * * !)$ and contain identical memories of frequent grabbing, pushing, beating of a mother or other relatives $\left(0.416^{*}\right)$, violence or humiliation at school $\left(0.416^{*}\right)$ and divorce or separate residence of parents $(0.373 *)$. Also children from such families were more often than others brought up with the attitude of "failure to succeed in life" $(0.372 *)$.

In families where abuses and humiliations were common we found memories about regular beatings to bruises $\left(0.673^{*}\right)$, lack of love and respect $\left(0.406^{*}\right)$, cases when there was no food and clothes to wear $\left(0.373^{*}\right)$ and cases of divorce and separate residence of parents $\left(0.587^{*}\right)$. Respondents grown in such environment also had high level of rejection from parents $\left(0.508^{*}\right)$. So again, this is a picture of a troubled family without a proper understanding of what a child is, how to care and how to treat them.

Question from the ACE questionnaire "Have you often or very often felt that you are not loved or respected?" has to do with the experience when parents were more worried about siblings $\left(0.390^{*}\right)$, humiliation and abuses $\left(0.406^{*}\right)$ and frequent beating to bruises $\left(0.492^{* *}\right)$. Not surprisingly, that such a set in family attitudes was able to instill in the child the idea that parents do not like him or her.

Among the negative events of childhood with extensive correlations are memories of bullying and school violence. Mostly this category included children who witnessed cruelty and armed threats between family members $\left(0.416^{*}\right)$, who lived with a mentally ill person $\left(0.416^{*}\right)$. Such respondents had negative correlation with socially desirable behavior $(-0.394 *)$ and the logical conclusion of the experience was and still is a feeling of rejection by their own parents $\left(-0.405^{*}\right)$.

Let's move on to the second part of the study, namely the impact of parental attitudes on negative children's experiences. And we can see two groups of parental attitudes patterns found in those families, where adults respondents had experienced traumatic psychological experiences in childhood. These are: acceptance-rejection and "little loser".

In particular, children who experienced a general emotionally negative attitude were more likely than others to experience situations of regular humiliation and resentment $\left(0.508^{*}\right)$, physical violence $\left(0.444^{*}\right)$, lack of love and respect from parents side $\left(0.403^{*}\right)$ and closeness and support within a family 
$\left(0.446^{*}\right)$. Regarding cases with a general emotionally positive attitude - the "acceptance" scale - our participants described families as loving and supportive (negative correlation with the question: "Were your family members not close, did not support each other?" ($0.432 *)$ ). The position of accepting own child perfectly coexists with the sincere desire of adults to cooperate with the child, show interest and participate in its affairs $\left(0.719^{* *}\right.$ on the scale "image of socially desirable behavior"). A child, who grows in such an environment has not faced with a situation of bullying or violence at school $\left(-0.045^{*}\right)$. Also there is a positive correlation with the scale of "symbiosis" $\left(0.507^{*}\right)$ - which is characterized as contact, the desire to be closer to the child, to meet his/her needs, to protect from trouble and more. So it's not surprising that the last two scales of the methodology are interconnected and have a significant correlation $\left(0.629^{* *}\right)$.

The second group concerns the scale of "infantilization" or "little loser". In this position, the child is perceived as an "incomprehensible creature", parents have lack of respect for their child thoughts and feelings, there is no focus on raising a child as an independent, free or open minded, and adult's attitude does not correspond to the age of a kid. Respondents who grew up in families with a mentally ill person, or who repeatedly witnessed armed threats to the mother or other family members, faced with this type of parental attitude (0.372* - a positive correlation in both cases). In addition, this type of interaction with the child can occur in families with such a behavioral factor of parental attitude as authoritarian hyper socialization $\left(0.377^{*}\right)$, which is based on the lack of equality and the presence of psychological distance between parents and child.

\section{Discussion}

Let us consider common and different points in this and some previous studies (Felitti, Anda, Nordenberg, Williamson, Spitz, Edwards, Koss, Marks, 1998; Ortiz, Sibinga, 2017; Tselikova, 2019; Preethy, Somasundaram, 2020). The first thing to pay attention is the difference in types of negative childhood memories and age. Compared to the previous work (Tselikova, 2019), which covered respondents whose age did not exceed 2324 years old, in this case we were dealing with the older generation and were able to see what exactly prevails in the memories of children of 80-90 ${ }^{\text {th }}$. It is clear that the percentage of troubled childhood was higher 20-30 years ago. In particular, the problem of lack of food or clean clothes were not usual in the sample of young people from the first study. What is this about? As for me the economic crisis of the 90s had its influence. Increased crime activity, economic downturn and other factors could affect the living conditions of working-class families, create the basis for growing alcohol or drug addiction statistics, parents may fall into the category of temporarily unable to cover basic family needs, and so children faced with more neglect than the following generation. Another difference is the percentage of traumatic memories. Thus, if in the previous study $67 \%$ of respondents had up to 5 negative childhood memories, then in the current one $-40 \%$. And those adults, who could remember from 11 to 15 such situations increased by $6 \%$. A common feature in both studies is the absence of cases of imprisonment of family members. As already mentioned, the ACE 
questionnaire was developed in the United States of America, so the largest research was conducted in this country (Felitti, Anda, Nordenberg, Williamson, Spitz, Edwards, Koss, Marks, 1998). Therefore, if we ask about the expansion of the intensity and breadth of traumatic psychological experiences gained in childhood in Ukraine, we can take data from the latest developments in the United States. According to the results on ACE questionnaire published in the United States in 2017, the majority (69\%) has one "yes" out of 10 , and $9 \%$ have stored up to 5 such memories (Ortiz, Sibinga, 2017). Our current study shows, that childhood traumatic experience is still wide, although, compared to the previous work (Tselikova, 2019), it is clearly a better picture.

\section{Conclusion}

The analysis of negative childhood experience with a combination of parental attitude allowed us to identify significant correlations between these factors and draw the following inference. As we can see from the full range of potential traumatic experiences, such as physical, sexual abuse, emotional neglect, substance addiction within a family, imprisonment or suicide, the most critical and harmful for a child are two - living with a mentally ill person or being witness of regular armed threats against the mother or family members. In such environment our respondents experienced: divorce or separate residence of parents, regular physical violence against mother or other relatives and school bulling. In such families, children did not feel accepted, supported or understood.

Also significant results have been found about family members behavior and attitude, which lead to creating psychologically unhealthy environment for a child. Such patterns as infantilizing, contemptuous attitude which does not imply a desire to see the child independent, mature and open, having cold or distant relationship with a kid - are the most frequent within families in difficult life circumstances. Childhood memories of regular insults and oppression, bruises, lack of support, love and respect from parent's side were common in families, where parental attitude was around reject and general negative vision of a child. Respondents from such families also experienced range of other negative situations in their childhood, which can become an obstacle for happiness in adulthood. In particular, in the process of communicating with others, manifestations of aggression, anxiety, rigidity, frustration, ability or inability to empathize, self-esteem issues, tolerance or lack thereof, building healthy relationship, propensity to codependence. So we are planning to continue the study, by covering wider range of possible features, which a person suffer from in their adult life and which might have roots in early age. These are the subjects for further researches.

\section{References}

Adler A. (2002). Individual'naya psikhologiya kak put' $\mathrm{k}$ poznaniyu lyudey i samopoznaniyu. Ocherki po individual'noy psikhologii. M.: Kogito-Tsentr.

Bevz, H. (2009). Dytyna u strukturi "identyfikatsiynoyi matrytsi" dorosloho. Problemy zahal'noyi ta zarubizhnoyi psykholohiyi. Zbirnyk naukovykh prats' Instytutu psykholohiyi im. H.S. Kostyuka APN Ukrayiny, za redaktsiyeyu 
akademika

11(2), 24-29.

S. D. Maksymenka,

Bruhn A.R. (1990). Cognitive perceptual model and the projective use of autobiographical memory. Journal of Personality Assessment, Vol. 55. 95-114.

Burmenskaya G.V., Karabanova O.A., Liders A.G. (1990). Vozrastnopsikhologicheskoye

konsul'tirovaniye. Problemy psikhicheskogo razvitiya detey. M.: Izd-vo MGU.

Felitti V. J., Anda R. F., Nordenberg D., Williamson D. F., Spitz A. M., Edwards V., Koss M. P., Marks J. S. (1998). Relationship of Childhood Abuse and Household Dysfunction to Many of the Leading Causes of Death in Adults. The Adverse Childhood Experiences (ACE) Study // American Journal of Preventive Medicine, 14(4), 245-258. DOI: https://doi.org/10.1016/S07493797(98)00017-8

Freud S. (1960). Childhood memories and screen memories. The complete psychological works of Sigmund Freud. Ed. \& Trans. J. Strachey. XXIII v. - London, Hogarth, vol.VI, $43-52$.

Golubeva Ye.V., Istratova O.N. (2009) Diagnostika tipov detskoroditel'skikh otnosheniy. Rossiyskiy psikhologicheskiy zhurnal. Rostovna Donu, 6(1), 25-34.

Kaplan S.J., Pelcovitz D., Bruna V. (1999). Child and Adolescent Abuse and Neglect Research: A Review of the Past 10 Years. Part I: Physical and Emotional Abuse and Neglect // Journal of the American Academy of
Child \& Adolescent Psychiatry. New York, 38 (10), 1214-1222.

Maksymova N. YU. (2011). Simeyne konsul'tuvannya. $\quad \mathrm{K}$.: $\quad$ DP «Vydavnychyy dim Personal».

Milyutina K. L. (2018). Model' empirychnoho doslidzhennya naslidkiv dytyachoho dosvidu $u$ doroslomu zhytti // Problemy suchasnoyi psykholohiyi: zbirnyk naukovykh prats' Zaporiz'koho natsional'noho universytetu ta Instytutu psykholohiyi im. H.S.Kostyuka NAPN Ukrayiny / Za red. S.D.Maksymenka, N.F.Shevchenko, M.H.Tkalych, 2 (14), 78-83.

Ortiz R., Sibinga E.M. (2017). The Role of Mindfulness in Reducing the Adverse Effects of Childhood Stress and Trauma. Children (Basel) 4(3): 16 , 87-99. doi:10.3390/children4030016

Petersen A.C., Aber J.L., Billingsley A., Brooks-Gunn J., Cohen D.J., Cohen M.I., Conte J.R., Egeland B., Hetherington E.M., Horwitz S.M., Korbin L.E., Lewis D.O., Little R.J.A., Straus M.A., Widom C.S., Wyatt G., Chalk R., Backer J., MacGuffie D.

(1993).

Understanding Child Abuse and Neglect. Neglect Panel on Research on Child. The National Academies Press. Washington. https://doi.org/10.17226/2117

Preethy N.A., Somasundaram S. (2020). Awareness of child abuse and neglect among working parents in Chennai, India: A knowledge, attitude and practice (KAP) survey // Journal of Family Medicine and 
Primary Care. Official journal of the academy of Family Physicians of India. 602-608. doi:10.4103/jfmpc.jfmpc_1106_19

Titarenko V. YA. (1987). Sem'ya i formirovaniye lichnosti. M.: Mysl'. Tselikova YU.O. (2018). Stupin' proyavu ta vydy nehatyvnoho dytyachoho dosvidu sered dorosloho naselennya Ukrayiny. Problemy suchasnoyi psykholohiyi: zbirnyk naukovykh prats' Zaporiz'koho natsional'noho universytetu ta Instytutu psykholohiyi imeni H.S. Kostyuka NAPN Ukrayiny. Za red. S.D. Maksymenka, N.F. Shevchenko, M.H. Tkalych., 1(15), 141-146.

Varga A. YA. (1987). Struktura i tipy roditel'skogo otnosheniya. Avtoreferat dissertatsii kandidata psikhologicheskikh nauk, M.: Promedia, 29 https://rucont.ru/efd/296562 